\title{
Commodification Practices in the Begawe Sasak's Lombok Tradition
}

\author{
Abdul Rahim \\ Fakultas Ushuluddin dan Studi Agama, Universitas Islam Negeri Mataram, Indonesia \\ email: abdul.rahim@uinmataram.ac.id \\ Halimatuzzahro \\ Faculty of Aqidah wa Falsafah, Al Azhar University, Cairo, Egypt \\ email: halimatuzzahro11@gmail.com
}

\begin{abstract}
The begawe tradition, which has become the popular culture of Sasaknese, has begun shifted by the consumption of mass cultures, such as catering services, the use of tools or begawe needs, starting to be replaced by industrial products for rent or sale. The forms of commodification in the begawe tradition, especially in begibung (eating together) and betulung (helping each other), two things that become the 'aura' of begawe. This difference can be seen from the shifting values, from the principle of kinship to individualism; of various equipment that is transformed and then commercialized. The new ethnography in this case study becomes the basis for examining the commodification practice in the begawe tradition, which switches to catering services and traditional equipment and replaces by modern equipment. The author, who is part of the Sasak community, also takes a participatory approach in begawe events held by the community. This shows that the alienation of popular culture in society cannot be contained by massive mass culture, so that people, which were initially established with high social values, began to form individualist societies that competed to show their social status. The consumption of
\end{abstract}

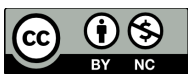

DOI: $10.19105 /$ karsa.v29i1.4455 
signs/symbols has formed a society trapped in a pseudo-need that is unwittingly oppressive. Awareness to be critical and filter the mass culture needs a sphere for negotiation to return the spirit of the social community based on kinship interaction.

[Tradisi begawe yang menjadi budaya populer Suku Sasak mulai tergeser dengan konsumsi budaya massa, seperti jasa katering, penggunaan alat-alat atau kebutuhan begawe mulai tergantikan dengan produk industri yang disewakan atau dijual. Bentuk-bentuk komodifikasi dalam tradisi begawe yang utama yakni begibung (makan bersama) dan betulung (saling bantu) merupakan dua hal yang menjadi 'aura' begawe. Perbedaan tersebut dapat dilihat dari nilai-nilai yang bergeser, dari asas kekeluargaan menjadi individualistis; dari berbagai peralatan yang ditransformasi kemudian dikomersialkan. Etnografi baru dalam studi kasus ini menjadi dasar untuk mengkaji praktik komodifikasi dalam tradisi begawe, yang beralih ke jasa katering dan peralatan tradisional; serta digantikan oleh peralatan modern. Penulis yang merupakan bagian dari masyarakat Sasak juga mengambil pendekatan partisipatif dalam acara begawe yang diadakan masyarakat. Hal tersebut menunjukkan teralienasinya budaya popular dalam masyarakat tidak mampu dibendung dengan budaya massa yang masif, sehingga masyarakat yang awalnya mapan dengan nilai sosial yang tinggi, mulai terbentuk masyarakat individualis yang berkompetisi menunjukkan status sosial mereka. Konsumsi tanda/simbol telah membentuk masyarakat yang terjebak dalam kebutuhan semu yang tak disadari telah menindas. Penyadaran untuk kritis dan filter terhadap budaya massa tersebut perlu ruang negosiasi untuk mengembalikan marwah masyarakat sosial yang hakikatnya didasarkan pada interaksi kekeluargaan.]

Keywords: popular culture; mass culture; commodification; begawe, pseudo need

\section{Introduction}

Before transforming into a modern society, the tradition that became the hallmark of traditional society is a culture full of social values that the people firmly hold. After being crammed with popular culture and slowly being produced in mass quantities, massive developments increasingly form an industrialist society dominated by capital owners over popular culture and mass culture.

Popular culture is slowly shifting traditional culture that has been practiced for a long time by the community, which in this case, the



DOI: 10.19105/karsa.v29i1.4455 
author highlights what happened to the Sasak people in Wanasaba, East Lombok, West Nusa Tenggara. More specifically, the traces of the transition of traditional culture into popular culture, then the consumption of mass culture through the culture industry, which is growing with the uncritical of its people. He pretexts of convenience or practicality through the mass culture, shifting the social roles of the people that have been intertwined for generations.

Ironically, despite losing many heritages of noble values, people are "accustomed to" consuming the growing popular culture and eventually birth to an industrial society that capital owners dominate. They seem not to realize that they have been oppressed by the false consciousness that is stuffed by the capitalists.

The case of cultural commodification in the begawe (celebration) tradition is very visible how the shift in people's lifestyles in the consumption of mass culture which industrialized by the capitalist. Begawe as a tradition in the traditional culture of the Sasak people, undergoes a transformation into mass culture consumerism when the interests of profit are entered by the capitalist. The value of solidarity embedded in the Sasak community through social interaction in the begawe tradition, shifted to an individualistic society when the industrialization of catering services, rental of tents, or the rental of buildings for begawe events began to flourish to try out local communities.

Commodification is a process closely associated with capitalism in which objects, qualities, and signs are transformed into commodities. Commodities themselves are understood as goods whose main purpose of existence is to be sold in the market. In the process that Marx calls "commodity fetishism", the appearance of goods sold in the market actually hides the origin of the goods that have to go through a process of exploitation at the level of production. ${ }^{1}$

Problems that arise when the begawe tradition is no longer culture, society's individualistic attitude begins to form. Then the principle of kinship that has been established in society was eroded by the

${ }^{1}$ Chris Barker, The Sage Dictionary of Cultural Studies (London : Sage Publications, 2003), 41-42.

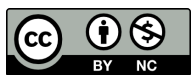

DOI: 10.19105/karsa.v29i1.4455 
inclusion of industrialization in this cultural practice. Ironically, despite losing many heritages of noble values, people are 'accustomed to' consuming the growing popular culture and eventually gave birth to an industrial society dominated by capital owners. They seem not to realize that they have been oppressed by the false consciousness that the capitalists stuff.

This is the real cultural crisis when people are used to the "pseudo-beauty" that exists. So it is not surprising that Adorno, one of the intellectuals of the Frankfurt School, said that a crisis occurs when things are already beautiful. For example, the cultural crisis that took place in the Sasak community in Lombok, NTB. The crisis can be seen in the implementation of the begawe tradition which has been reified by several developing capitalist tools. In the begawe procession, there are begibung and betulung processions that become the 'aura'. However, nowadays, this has been shifted by catering services and the buffet concept, which is basically a capitalist product to form a cultural industry. As a result, the community that initially upholds the values of kinship and the spirit of mutual cooperation has now become an individualistic society.

This article tries to reveal how the life line of the Sasak community, which is based on kinship, and the value of solidarity built in the begawe tradition began to be eroded by the entry of mass culture through the industrialization of services, which affected the social order of the community. Besides, the practice of consuming mass culture also eliminates the role of traditional cultural products and forms a modern society which is actually oppressed by the pseudo-needs and desires of consumerism.

As revealed by John Fiske that popular culture is a culture that is created from its own people without profit interests. ${ }^{2}$ However, when the popular culture has penetrated the mass-produced industrialization process, the commercialization process for the mass culture is no longer affiliated with social values or relying on the solidarity of the community, but what are the benefits of these commercialized products. Associated with social values cannot be separated from the public's

${ }^{2}$ John Fiske, Understanding Popular Culture (Yogyakarta : Jalasutra, 2011), 12-17.

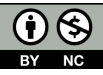

DOI: $10.19105 /$ karsa.v29i1.4455 
receptiveness to the mass culture, which is trapped in the consumption of texts for the needs offered through the media, be it advertising, radio, television, and others.

This is also where it can be seen how the cultural industry that is testing society has collided with concepts such as the one introduced by Fiske about pseudo needs and true needs. The two concepts can vaguely claim to each other that something is indeed a true need and can also be a pseudo need. The receptive foresight of the culture-loving community is needed to filter this out so that people are no longer trapped to consume signs for the products offered by industry.

In the concept of mass culture, people's needs are grayed out between pseudo needs and true needs. The needs of the community seem to be captured by the industry, in this case, the owners of capital (capitalists), so that they freely offer products that are not a community need for use-value actually, but turn into the consumption of sign values and symbolically to grab attention and strengthen the social status of the user. $^{3}$

Adorno in The Culture Industry explains that the overall practice in the culture industry transfers profit motives into cultural forms. ${ }^{4}$ In this context, the statement describes the term commodification. Theoretically, Marx said that commodification explains the capitalist way to maintain a goal of realizing use value to exchange value. He wants to explain that the use-value of an object is in line with the exchange value so that the authentic value of the object automatically disappears. ${ }^{5}$

Adorno's concept of the culture industry which he argues that uniformed and standardized commodities will foster the spirit of authoritarianism and conformism as the dominant face of Western capitalist culture. ${ }^{6}$ Another view is put forward by Jürgen Habermas, who argues that the increasing commodification of the living world by giant

${ }^{3}$ Dominic Strinarti, Popular Culture : Pengantar Menuju Teori Budaya Populer (Yogyakarta: Ruzz Media, 2009), 37.

${ }^{4}$ Theodor W. Adorno, The Culture Industry (New York: Routledge, 2001), 47-52.

5 Anthony Brewer, Kajian Kritis Das Kapital Karl Marx (Yogyakarta : NarasiPustaka, 2016), 36.

${ }^{6}$ Adorno, The Culture Industry, 47-52.

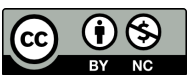

DOI: $10.19105 /$ karsa.v29i1.4455 
corporations will transform people from rational citizens into irrational consumers in the same way that existential social questions have degenerated into purely money-making issues. ${ }^{7}$ In the context of the begawe tradition, the pursuit of profit through new forms of the begawe tradition, which is symbolized on buffets and catering services, shows that the commodification behind it is the unavoidable product of capitalism in the life of the Sasak people.

Adorno and Horkheimer also write that commodification occur as a result of the development of a culture industry. Adorno says that the culture industry has become a crucial economic and political factor in the late capitalism era, which distracts people from the problems they actually experience and offers false solutions projected into the "life" of fictional characters encoded into sweet harmony. ${ }^{8}$ In this regard, society seems to be consumed by popular culture, which follows under the pretext of modernity. This culture erodes the noble values that have been inherited. Walter Benjamin also expresses that a new spirit can indeed be obtained, but the old aesthetic sensibility has disappeared. ${ }^{9}$

However, in the era of globalization with the capitalist system, there has been a cultural explosion in all aspects of life, so in this case, industry has produced various cultural artifacts that seem to have become the needs of the masses. The cultural objects that were previously filled with high values are authentic (authenticity) and truth, by the culture industry, mass-produced into a commodity full of profit calculations. ${ }^{10}$

On the other hand, a postmodern thinker, Jean Baudrillard, argues that sign-value has replaced the use value and exchange value of commodities in contemporary culture. In contemporary culture, value is determined through the exchange of symbolic meanings rather than

\footnotetext{
7 Jürgen Habermas, Teori Tindakan Komunikatif I: Rasio dan Rasionalisasi Masyarakat, trans. Alimandan (Yogyakarta: Kreasi Wacana, 2007), 72-81.

${ }^{8}$ Ben Agger, Teori Sosial Kritis (Yogyakarta: Kreasi Wacana, 2014), 46-49.

${ }^{9}$ Greg Soetomo, Krisis Seni Krisis Kebudayaan (Yogyakarta: Pustaka Filsafat, 2003), 33.

${ }^{10}$ Valentina Tutu Paok, "Komodifikasi dalam Program Pengembangan Seni Budaya di Jogja TV," (master thesis, Fakultas Ilmu Sosial dan Ilmu Politik, Universitas Atma Jaya Yogyakarta, 2012).
}

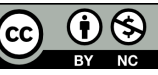

DOI: $10.19105 /$ karsa.v29i1.4455 
through their use. So the commodity is no longer an object with a usevalue but a commodity sign. According to this view, all spheres of life are markedly affected by commodification so that something is considered authentic or inauthentic no longer determined by validation based on formal canons or socially formed cultural authorities. ${ }^{11}$

The above can be seen when popular culture shifts traditional culture in society. The begawe tradition, which has the concept of begibung and betulung, has been shifted by the concept of using catering and buffet services. The last two things are capitalist tools to shift the "aura" in begawe.

The beginning concept is filled with the spirit of solidarity between residents, namely the concept of eating together in one container. Meanwhile, in begawe, the community works together to help those who have a celebration, either in the form of energy or material, in organizing the begawe ceremony. However, this spirit of "gotong royong" and solidarity has been lost in the concept of catering and buffet rental services. The form of working together is replaced by spending money by renting catering services. This is in accordance with what Marx called commodity fetishism, that it is built in every commodified relationship when workers exchange their labor for wages. ${ }^{12}$ The spirit of kinship and gotong-royong was replaced with money in the form of wages.

\section{Methods}

In tracing the commodification practices that occur in the begawe tradition of the Sasak people in Wanasaba, East Lombok, NTB, the author uses a new ethnographic method based on the view of Paula Saukko, which states that the involvement of researchers is directly involved in conducting dialogue or interviews, participation in the community being studied, and interpreting the scope of the study. ${ }^{13}$ The

\footnotetext{
${ }^{11}$ Jean Baudrillard, Masyarakat Konsumsi (Yogyakarta: Kreasi Wacana, 2004), 89.

${ }^{12}$ Agger, Teori Sosial Kritis, 46-49.

${ }^{13}$ Paula Saukko, Doing Research in Cultural Studies, An Introduction to Classical and New Methodological Approaches (London: Sage Publications, 2003), 54-65.
}

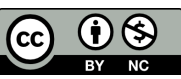

DOI: $10.19105 /$ karsa.v29i1.4455 
object under study is based on the reflection of the researcher. Specifically, the use of the new ethnography in this case study becomes the basis for conducting a closer study of the commodification practice in the begawe tradition, which switches to catering services, as well as the use of traditional equipment, which is replaced with modern equipment with the assumption of effectiveness.

The author, who is part of the Sasak community, also takes a participatory approach in begawe events held by the community. The author makes observations on residents who have a celebration, who prefer catering services as a banquet in the form of a buffet rather than carrying out begawe events that can be assisted by the surrounding community.

The basis of Saukko's new ethnographic method of selfreflexivity is also used by the author in observing the practice of cultural commodification, which is entered by the products of capitalist industrialization. The product of industrialization in the practice of begawe when residents prefer to use catering services or rent a building in the event has alienated social values that exist in society because there is no interaction between residents in helping the master's celebration. The masters of the celebration (epen gawe) who think about the effectiveness and convenience of the event by renting a building and catering services are not aware of the social impact that arises from reduced solidarity in society.

The new ethnographic method based on Saukko's review in this case study is used by the author because it relates to the closeness of the author in the community under study. Likewise, the dialogical validity or self-reflection, which is the basis of the new ethnography, in expressing the voices of the object understudy in the form of polyvocality, the authors put it in the form of participatory research in the Sasak community in Wanasaba, East Lombok, NTB.

\section{Results}

\section{Begawe Transformation (Hajatan) Using Catering Services}

The case study that the author observes is about the shift from Traditional culture to popular culture and then transformed into mass culture, namely about the begawe (celebration) that has occurred in

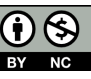

DOI: $10.19105 /$ karsa.v29i1.4455 
Sasak society historically to date. Begawe literally means an event (celebration) for an activity that is in the community in the context of thanksgiving or commemorating something by inviting many people to help or attending as guests. ${ }^{14}$ The concept of begawe has various cultural values. These concepts include the existence of betulung and begibung activities. This is what makes begawe have what Walter Benjamin calls an "aura". ${ }^{15}$

Today, the tradition of begawe is still carried out by the Sasak people of Lombok. However, there are differences in the way the activities are carried out. Researchers who are natives of the Sasak tribe have observed the developments that occur, especially in each series of events. It can be said that the begawe at the time of the researcher was in the midst of the Sasak people in the past, had a significant difference. Begawe in the past still apply begibung, and there are tekot $^{16}$, invitations by way of mensilaq, and several other begawe processions. However, currently, observations show that these activities have transformed massively. One example is how to invite guests by sending an invitation letter or through social media. This is now common place in society. In fact, they feel comfortable and happy to do so. However, after being investigated and researched, in the "comfort zone", there is a tendency for commodification practices in it.

If in the past, when the writer was child (in 1995-2003), begawe at that time was still colored with the nuances of community solidarity that was still thick. The immediate family helps materially by providing the necessities for begawe, such as rice, spices for seasoning, or in the form of money to purchase these necessities. In addition, the neighbors around, before, until the D-day of the begawe held, they helped to prepare everything at the house of the owner of the gawe (epen gawe). Such as helping to make ketaring (teratak, tent) shade from woven coconut leaves with bamboo poles, helping to collect firewood for

\footnotetext{
${ }^{14}$ Lalu Wacana, Pulau Lombok dalam Sejarah Ditinjau dari Aspek Budaya (Jakarta: Depdikbud, 1987).

${ }^{15}$ Walter Benjamin, Work of Art in the Age of Its Technological Reproducibility, and Other Writings on Media (Massachusetts: Harvard University Press, 2008), 18.

16 The container formed from banana's leaf
}

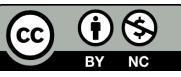

DOI: $10.19105 /$ karsa.v29i1.4455 
cooking purposes, helping to peel coconuts, or preparing ingredients for other begawe.

The begawe procession by involving neighbors and inviting many people requires certainly a large amount of money to fulfill the preparations for the invited guests. So this is where the function of the help of neighbors and close family who have been prepared in advance is here. At the level of mutual assistance with the term violator (donation) to the owner of the game, this can be termed popular culture born from the community. Therein lies the value of solidarity between the people who will, also experience as the owner of gawe (epen gawe) later in their family, whether it is for aqiqah (birthday celebration, the Sasak term of ngurisang), sunatan $^{17}$, marriage, or begawe commemorating when a family member was passed by.

Then what became the highlight of the industrialization process in this begawe culture, when people were already popular with begawe, helping each other in preparation, were caught by the capitalist by trying to promote catering facilities when someone had a celebration (begawe). The cost for catering is also quite expensive, and usually can only be rented by certain groups who have a large capital. The begawe process, which involves many people, begins to shift when catering services play a role, the value of solidarity between neighbors begins to fade. Even though the actual begawe procession is not just a thanksgiving event, but the fabric of close interaction between people is the important value. This is what Habermas reveals as social capital; the interaction between the community is the biggest need. ${ }^{18}$

When catering services began to spread, people who were still trying to revive the begawe culture seemed to lose their sensibility, like something was missing when the begawe, which used to be many people

\footnotetext{
17 "Sunatan" or circumcision in Islamic law is the removal of the skin flap which covers the balanus. By this removal, the body is relieved of a pocket where dirt, germs, fungi accumulate, focusing on impurity and offensive smell. Several medical studies have concluded that inflammation of the male genitals is higher among men who have not been circumcised.

18 Jürgen Habermas, Teori Tindakan Komunikatif I: Rasio dan Rasionalisasi Masyarakat, trans. Alimandan, 72
}

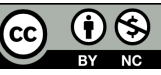

DOI: $10.19105 /$ karsa.v29i1.4455 
involved in helping, slowly started to ignore it and let things happen as if it happened naturally. Whereas when someone tries to echo the value of solidarity, the community should also respond actively to restore the dignity of the social community that has high solidarity to help each other.

Every society and its culture, no matter where it is located, is always experiencing development or change with all the consequences that accompany it, either because internal or external forces drive it. Internal strength can grow naturally due to the alternation of generations. On the other hand, external forces occur due to environmental changes as well as interactions/contacts with other communities and cultures through the diffusion and borrowing of foreign cultural elements, thereby stimulating renewal in their absorption. ${ }^{19}$ Thus, the development of socio-cultural functions experienced the distribution of functions from one member to another, so that the differentiation of society became increasingly complex. ${ }^{20}$

The change process due to one's touch and absorption of a new knowledge system will provide a new way of interpretation and meaning to the existing order. Based on this, Sumadi categorizes people into two groups due to cultural changes in society. First, the elderly groups, those classified as already established in their lives, tend to stick closely to the culture that raised them and are always used as a frame of reference in achieving success. Second, the next generation group prioritizes their attention on the challenges of the times and responds to changes following the demands of the change itself.

Therefore, this group always easily adopts cultural values, social norms, or ways of life regardless of their origins. For future generations, the most important thing is that they can deal with the problems they face effectively and efficiently and often ignore the old culture they already have. globalization has significant influence on the development of culture and customs in society. Millennial generation as an active

19 I Wayan Suca Sumadi, et al., Tradisi Nyongkolan dan Eksistensinya di Pulau Lombok (Yogyakarta: Penerbit Ombak, 2013), 22-27.

${ }^{20}$ A.A. Ngr. Anom Kumbara, "Konstruksi Identitas Orang Sasak di Lombok Timur NTB," Humaniora, 20, no. 3 (2008): 315-326, https://doi.org/10.22146/jh.947.

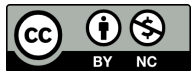

DOI: $10.19105 /$ karsa.v29i1.4455 
subject of globalization has a tendency to imitate the various cultures of the world, and leave indigenous culture inherited from the previous generation. ${ }^{21}$

The conflict between the two groups above is also seen in the Sasak people of Lombok, especially in the procession of the begawe tradition. As a tradition, begawe has an authentic value that makes it a sacred activity carried out by the community. However, the current globalization, especially the contestation of the capitalists, took part in creating industrial products to shift existing traditions. Finally, the practice of commodification a tradition is difficult to avoid. Tradition and local wisdom that still prevail in the community has the potential to encourage the desire to live harmonious and peaceful. It still has sacred value and emphasizes the values of humanity, togetherness, brotherhood and attitudes and not on individual values. Indonesian society is very plural in many aspects and still holds strong custom and tradition. ${ }^{22}$ Through education gathered from school, a system of values and culture which are believed and applied in a particular society can be studied, developed, internalized, and transformed; that is why it is possible to continue to be sustainable. ${ }^{23}$

The authentic value in the begawe above now seems to have disappeared due to being oppressed by the creative activities of the capitalists who see opportunities in every series of begawe events. The capitalists, under the pretext of being modern, more efficient, and practical, created alternatives in the form of catering and buffet services to replace begibung and betung. Ironically, with people's uncritical view of the symptoms of this cultural crisis, they are trapped in the conceptions offered by the capitalists. This is in accordance with what

\footnotetext{
${ }^{21}$ Hamlan Andi Baso Malla et al., "Indigenous Monikah Tajio Ethnic of Islamic Cultural Heritage at Kasimbar, Central Sulawes," Karsa: Journal of Social and Islamic Culture 28, no. 2 (2020): 5, https://doi.org/10.19105/karsa.v28i2.3301.

${ }^{22}$ Fitri Yanti, et al., "Ngababali Tradition on Islamic Religious Practice in The Negeri Besar Village, Way Kanan, Lampung Province," Karsa: Journal of Social and Islamic Culture 26, no. 2 (2018): 4, htttps://doi.org/10.19105/karsa.v26i2.2043.

${ }^{23}$ Ashif Az Zafi, "Transformasi Budaya Melalui Lembaga Pendidikan (Pembudayaan dalam Pembentukan Karakter)," SOSIOHUMANIORA: Jurnal Ilmiah Ilmu Sosial dan Humaniora 3, no. 2 (2017): 110, https://doi.org/10.30738/sosio.v3i2.937.
}

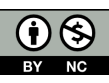

DOI: $10.19105 /$ karsa.v29i1.4455 
is described by Hasan, that there has been a daily aesthetic in today's life, namely a condition when art or culture is continuously present along with the interests of the capital that rides it. ${ }^{24}$ As a result, the culture can no longer be seen as something exclusive or autonomous.

\section{Industrialization of Community Needs}

Many things are also commodified in the begawe tradition or the transition from the beginning concept to catering or buffet services. The begibung procession is a joint dining activity carried out by the community (Banjar ${ }^{25}$ and invited guests) using a dulang. ${ }^{26}$ This activity is carried out after the roah event is completed. Roah itself is a prayer reading activity led by a cleric or "kiai" which is only attended by men. While the women were busy preparing the trays.

On the other hand, the prasmanan or buffet is a way of presenting food at a party (begawe) by placing various dishes on a long table, and the invited guests take the desired food menu themselves. The long table (rijsttafel) used in the buffet is a Dutch household utensil that is usually used to serve various foods at various events. ${ }^{27}$ It can be seen that there are clear differences between the two, namely mainly in terms of shifting values, as well as in some means of production.

In addition, the factors that cause this commodification include the use of plastic wrap for side dishes, which is increasingly dominating, even though usually every begawe uses banana leaves clamped with sticks at two ends (rondon) as a container for side dishes that are given to invited guests to take home. In addition, the use of pandan leaf ${ }^{28}$ woven mats began to shift to the use of plastic carpet mats, or the use of

24 Sandi Suwardi Hasan, Pengantar Cultural Studies: Sejarah, Pendekatan Konseptual, dan Isu Menuju Studi Budaya Kapitalisme Lanjut (Yogyakarta: Ar-Ruz Media, 2011), 6.

${ }^{25}$ Groups within a village; one village consists of several Banjar.

${ }^{26}$ It is a dish consisting of rice and various typical Sasak side dishes in one tray.

${ }^{27}$ Djoko Soekiman, Kebudayaan Indis: dan Gaya Hidup Masyarakat Pendukungnya di Jawa Abad XVIII-Medio Abad XX (Yogyakarta: Bentang Pustaka,2000), 76.

${ }^{28}$ Pandanus amaryllifolius is a tropical plant in the Pandanus (screwpine) genus, which is commonly known as pandan (/'pændən/). It has fragrant leaves which are used widely for flavouring in the cuisines of Southeast Asia and South Asia.

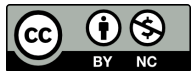

DOI: $10.19105 /$ karsa.v29i1.4455 
firewood during begawe events was replaced by the use of gas stoves for cooking activities.

The factors that cause the entry of industrial products into a traditional culture or popular culture cannot be separated from the mediating influence on that culture which is captured by the capitalists. For example, when begawe requires a lot of time, energy, and place to carry out, when it is captured by the capitalists as an opportunity to market products, catering services are provided, tent rental services (tents), place rental services for complete begawe (celebration) events are provided. Initially trying out modern urban society, now it has begun to penetrate the lives of traditional people in the villages. Efficiency, convenience, and the availability of space for the availability of needs in carrying out begawe events are an attraction for people who do not want to be bothered when having a celebration, such as during weddings, aqiqah ${ }^{29}$, and others.

Begawe, with the spirit of brotherhood that has been built, has begun to shift to rental service products offered by capital owners. Conservative thinking could be that many think begawe is a form of consumerism, a procession that wastes much money just for an event. However, the support for the continuity and involvement of the community at the event shows that social values in society are still maintained. Unlike the case when the use of catering services and the rental of venues for celebrations, a society with an individualistic attitude will begin to form, and slowly there will be no more social space that characterizes traditional rural communities.

Raymond Williams expressed that popular culture born from the community, when mediated and becomes mass culture, will shift popular culture and traditional culture embedded in society. ${ }^{30}$ Mass culture that is increasingly massive then becomes a habitus that can become domination and needs that the capitalists cram. For example, they use plastic for almost all needs. In the past, market snacks used

\footnotetext{
29 Aqiqqah (Arabic: عقيقة), aqeeqa, or aqeeqah is the Islamic tradition of the sacrifice of an animal on the occasion of a child's birth.

${ }^{30}$ Chris Barker, Cultural Studies: Teori dan Praktik (Yogyakarta: Kreasi Wacana, 2004), 134.
}

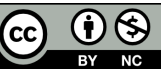

DOI: $10.19105 /$ karsa.v29i1.4455 
banana leaf wrappers, and now all use plastic. After knowing the impact of plastic on the environment, a campaign to reduce the use of plastic began, but people are already dependent on plastic. They cannot be separated from using it, and the plastic producers cannot immediately stop their products which will have an impact on reducing their profits.

When they reach the age of 5-6 years, Sasak women have begun to be taught to weave pandan mats as a symbol that they are truly women and part of society. In the past, when there was a girl who could not weave a pandan mat, she would be ridiculed, even though her parents' socio-economic status was well-off. ${ }^{31}$

When the production of pandan mats began to recede, the production process also took a long time (about three days or more, for a pandan mat size of $1.5 \times 2$ meters). In contrast, the regeneration of weavers of pandan mats among Sasak women was no longer cult as a woman's identity. Sasak, this is where the production of plastic carpets began to enter the community.

Likewise, when the use of woven pandanus mats, which were originally woven for household purposes, has now turned to the use of plastic carpets, there is even a motif of woven pandan mats. Pandan mats were originally a product of the community; even some people needed woven pandan mats to replace the cost of making them with rice. Here the barter process still occurs, it does not mean they are not popular with money, but when exchanging goods, the family value is still the basis popular in society.

\section{Discussion}

People with the consumptive type and affordability to buy industrial products have unconsciously been oppressed by capitalist products. Even though with adequate natural resources in the form of pandanus trees that grow a lot around them, but when they are crammed with the concept of convenience offered by industrial products, they do

\footnotetext{
${ }^{31}$ Abdul Rahim and Wisma Nugraha Christianto, "Negosiasi Atas Adat dalam Sistem Pelaksanaan Tradisi Nyongkolan Sasak Lombok," Jurnal Kawistara 9, no. 1 (2019): 13, https://doi.org/10.22146/kawistara.36125.
}

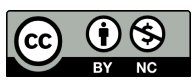

DOI: $10.19105 /$ karsa.v29i1.4455 
not think about producing their own products, they can even become commodities in the community to be marketed go out.

Residents with middle to upper socio-economic status on average, prefer to use catering services rather than being bothered with begawe events on the grounds that they require a lot of free time and lots of preparation. Meanwhile, it is considered more effective and easier when using catering services, even if it is calculated nominally at a higher cost.

Likewise with the author's observations when residents rent buildings for events, assuming their homes or yards are not big enough to accommodate guests and equipment they do not have. Meanwhile, renting a building for a celebration is complete with table equipment, chairs, protected from heat or rain, and even consumption from catering services in collaboration with the building management. For example, residents who rent a convention hall building, or the auditorium of certain institutions, by paying more they get adequate facilities for a celebration than at home.

The author's observation of residents who do not carry out begawe at home and prefer to rent buildings and catering services also articulates their social status identity. The dialogue with the middle to upper economic class residents who rent the building and catering services prioritizes time efficiency and convenience in their events or celebrations to entertain guests. In addition, the perception of effectiveness when renting a building or catering services is felt to be more respectful of guests. It shows the social status of residents who have a celebration.

The authentic value in the begawe above now seems to have disappeared due to being oppressed by the creative activities of the capitalists who see opportunities in every series of begawe events. The capitalists, under the pretext of being modern, more efficient, and practical, created alternatives in the form of catering and buffet services to replace begibung and betung. Ironically, with people's uncritical view of the symptoms of this cultural crisis, they are trapped in the conceptions offered by the capitalists. This is in accordance with what is described by Hasan, that there has been a daily aesthetic in today's life, namely a condition when art or culture is continuously present along

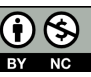

DOI: $10.19105 /$ karsa.v29i1.4455 
with the interests of the capital that rides it. ${ }^{32}$ The culture cannot be seen longer as something exclusive or autonomous.

In addition, the practice of cultural industrialization is also seen when the use of catering services replaces the services of betulung in the begawe tradition. The owner of the celebration prefers to hire an Event Organizer (EO) to coordinate the event and leave the local community to help organize the celebration. Finally, the social impact caused is the birth of an individualist and consumeristic society due to the shift in popular culture towards the begawe tradition.

The problem of culture as an industry raises questions about cultural materialism and cultural commodification, creative consumption, and the dangers of a reducing view. ${ }^{33}$ The reductionism referred to here is seen in the increasingly narrow community interactions, when an established tradition with social values is drawn to instant fulfillment through the products of capitalism under the pretext of effectiveness.

The process of cultural commodification, from popular culture to mass culture, is an unavoidable trigger for transforming traditional society into an individualistic modern society. When the value of the symbol shifts, the use-value is a marker of the social status of the people, and that is, suppression of pseudo-needs occurs and unconsciously. The concept of fetishism (satisfaction) which is the basis for capitalists, is responded to the beginning of the formation of mass culture. Then the mass culture that occurs in the Sasak community is a form of public frustration over their inability to filter and maintain their culture over the massive crowding of mass culture through mediation from advertisements that they continuously consume.

\section{Conclusion}

It was filled with mass culture from a society of high solidarity through offers of efficiency, convenience, and affordability for its

\footnotetext{
32 Sandi Suwardi Hasan, Pengantar Cultural Studies: Sejarah, Pendekatan Konseptual, dan Isu Menuju Studi Budaya Kapitalisme Lanjut (Yogyakarta: Ar-Ruz Media, 2011), 6 .

33 Theodore W. Adorno and Max Horkheimer, The Dialectic of Enlightenment (London: Verso, 1979), 16.
}

DOI: $10.19105 /$ karsa.v29i1.4455 
consumptive, making the community a passive subject. There is no room for negotiation to filter or criticize the social transformations that occur. Instead, society becomes compartmentalized for competition in gaining social status.

The space for public awareness to avoid a clash between staying confined and traditional culture amid the massive onslaught of mass culture raises a dilemma that must be addressed wisely. The consumptive type of society and the acute dependence on mass cultural products have increasingly made people neglect to be critical of the growing culture industry, and even more, have the potential to support the perpetuation of capitalists in exploiting all lines of people's lives.

\section{Bibliography}

Adorno, Theodor W., and Max Horkheimer. The Dialectic of Enlightenment. London: Verso, 1979.

Adorno, Theodor W., and J. M. Bernstein. The Culture Industry. New York: Routledge, 2001.

Agger, Ben. Teori Sosial Kritis. Yogyakarta: Kreasi Wacana, 2014.

Barker, Chris. Cultural Studies: Teori dan Praktik. Yogyakarta: Kreasi Wacana, 2004.

Barker, Chris. The Sage Dictionary of Cultural Studies. London: Sage Publications, 2003.

Baudrillard, Jean. Masyarakat Konsumsi. Yogyakarta: Kreasi Wacana, 2004.

Baudrillard, Jean. Simulacra and Simulations. New York: Semiotext, 1983.

Benjamin, Walter. Work of Art in the Age of Its Technological Reproducibility, and Other Writings on Media. Massachusetts: Harvard University Press: 2008.

Brewer, Anthony. Kajian Kritis Das Kapital Karl Marx. Yogyakarta: Narasi Pustaka, 2016.

Fiske, John. Memahami Budaya Populer. Yogyakarta: Jalasutra, 2011. Habermas, Jürgen. Teori Tindakan Komunikatif I: Rasio dan Rasionalisasi Masyarakat. Translated by Alimandan. Yogyakarta: Kreasi Wacana, 2007.

\section{(9) $(1)$}

DOI: $10.19105 /$ karsa.v29i1.4455 
Habermas, Jürgen. The Philosophical Discourse of Modernity. Cambridge: Polity Press, 1987.

Hasan, Sandi Suwardi. Pengantar Cultural Studies: Sejarah, Pendekatan Konseptual, dan Isu Menuju Studi Budaya Kapitalisme Lanjut. Yogyakarta: Ar-Ruz Media, 2011.

Kumbara, A.A. Ngr Anom. "Konstruksi Identitas Orang Sasak di Lombok Timur NTB." Humaniora 20, no. 3 (2008): 315-326. https://doi.org/10.22146/jh.947.

Malla, Hamlan Andi Baso, Khaeruddin Yusuf, and Nur Rohim Yunus, "Indigenous Monikah Tajio Ethnic of Islamic Cultural Heritage at Kasimbar, Central Sulawesi." Karsa: Journal of Social and Islamic Culture 28, no. 2 (2020): 363-389. https://doi.org/10. 19105/karsa.v28i2.3301.

Nye, Joseph S. Soft Power: The Means to Success in World Politics. New York: PublicAffairs, 2004.

Paok, Valentina Tutu. "Komodifikasi dalam Program Pengembangan Seni Budaya di Jogja TV." Tesis, Fakultas Ilmu Sosial dan Ilmu Politik, Universitas Atma Jaya Yogyakarta, 2012.

Rahim, Abdul and Wisma Nugraha Christianto. "Negosiasi Atas Adat dalam Sistem Pelaksanaan Tradisi Nyongkolan Sasak Lombok." Jurnal Kawistara 9, no. 1 (2019): 28-44. https://doi.org/10.22146/ kawistara.36125.

Saukko, Paula. Doing Research in Cultural Studies: An Introduction to Classical and New Methodological Approaches. London: Sage Publications, 2003.

Soekiman, Djoko. Kebudayaan Indis: dan Gaya Hidup Masyarakat Pendukungnya di Jawa Abad XVIII-Medio Abad XX. Yogyakarta: Bentang Pustaka, 2000.

Soetomo, Greg. Krisis Seni Krisis Kebudayaan. Yogyakarta: Pustaka Filsafat, 2003.

Storey, John. Cultural Studies dan Kajian Budaya Pop. Yogyakarta: Jalasutra, 2007.

Strinarti, Dominic. Popular Culture: Pengantar Menuju Teori Budaya Populer. Yogyakarta: Ruzz Media, 2009. 
Sumadi, I Wayan Suca, I Gusti Ngurah Jayanti, and Anak Agung Rai Geria. Tradisi Nyongkolan dan Eksistensinya di Pulau Lombok. Yogyakarta: Penerbit Ombak, 2013.

Wacana, Lalu. Pulau Lombok dalam Sejarah Ditinjau dari Aspek Budaya. Jakarta: Depdikbud, 1987.

Yanti, Fitri, Eni Amaliah, and Abdul Rahman "Ngababali Tradition on Islamic Religious Practice in The Negeri Besar Village, Way Kanan, Lampung Province." Karsa: Journal of Social and Islamic Culture 26, no. 2 (2018): 306-326. https://doi.org/10.19105/karsa. v26i2.2043.

Zafi, Ashif Az. "Transformasi Budaya Melalui Lembaga Pendidikan (Pembudayaan dalam Pembentukan Karakter)." SOSIOHUMANIORA: Jurnal Ilmiah Ilmu Sosial dan Humaniora 3, no. 2 (2017): 105-112. https://doi.org/10.30738/sosio.v3i2.937. 